\title{
BMJ Open Impact of political conflict on tuberculosis notifications in North-east Nigeria, Adamawa State: a 7-year retrospective analysis
}

\author{
Emmanuel Pembi, ${ }^{1}$ Stephen John, ${ }^{2}$ Shyam Prakash Dumre, ${ }^{3}$ \\ Baba Usman Ahmadu, ${ }^{4}$ Nguyen Lam Vuong, ${ }^{5}$ Amr Ebied, ${ }^{6}$ Shusaku Mizukami, ${ }^{3,7}$ \\ Nguyen Tien Huy, ${ }^{3,8}$ Luis E Cuevas, ${ }^{9}$ Kenji Hirayama (D) ${ }^{3}$
}

To cite: Pembi E, John S, Dumre SP, et al. Impact of political conflict on tuberculosis notifications in North-east Nigeria, Adamawa State: a 7-year retrospective analysis. BMJ Open 2020;10:e035263. doi:10.1136/ bmjopen-2019-035263

- Prepublication history for this paper is available online. To view these files, please visit the journal online (http://dx.doi org/10.1136/bmjopen-2019035263).

Received 08 November 2019 Revised 28 March 2020 Accepted 29 April 2020
Check for updates

(c) Author(s) (or their employer(s)) 2020. Re-use permitted under CC BY-NC. No commercial re-use. See rights and permissions. Published by BMJ.

For numbered affiliations see end of article.

Correspondence to Prof Kenji Hirayama; hiraken@nagasaki-u.ac.jp, Professor Luis E Cuevas; luis.cuevas@Istmed.ac.uk and Dr Nguyen Tien Huy; tienhuy@nagasaki-u.ac.jp

\section{ABSTRACT}

Objective We assessed the impact of political conflict (Boko Haram) on tuberculosis (TB) case notifications in Adamawa State in North-east Nigeria.

Design A retrospective analysis of TB case notifications from TB registers (2010-2016) to describe changes in TB notification, sex and age ratios by the degree of conflict by local government area.

Setting Adamawa State.

Participants 21076 TB cases notified.

Results 21076 cases ( $62 \%$ male) were notified between 2010 and 2016, of which 19604 (93\%) were new TB cases. Areas affected by conflict in 2014 and 2015 had decreased case notification while neighbouring areas reported increased case notifications. The male to female ratio of TB cases changed in areas in conflict with more female cases being notified. The young and elderly (1-14 and $>65$ years old) had low notifications in all areas, with a small increase in case notifications during the years of conflict.

Conclusion TB case notifications decreased in conflict areas and increased in areas without conflict. More males were notified during peace times and more female cases were reported from areas in conflict. Young and elderly populations had decreased case notifications but experienced a slight increase during the conflict years. These changes are likely to reflect population displacement and a dissimilar effect of conflict on the accessibility of services. TB services in conflict areas deserve further study to identify resilient approaches that could reach affected populations.

\section{INTRODUCTION}

Tuberculosis (TB) continues to be a major public health problem in Africa, especially in poor and insecure areas with limited access to services. ${ }^{1}$ TB services are especially at risk in areas with political disruption and conflict, and refugee and internally displaced populations (IDPs) frequently have limited access
Strengths and limitations of this study

- Being aggregated data, the study lacks sociodemographic granularity and individual patient information to warrant detailed exploration of associations and confounders.

- The data was collected from passive tuberculosis (TB) case finding, which does not allow estimating the real burden of TB in the state.

- We have shown that case notifications in local government areas (LGAs) in conflict areas decreased during the period of insurgency with compensating increases in case notifications in areas with low conflict, possibly reflecting population movement.

- To our knowledge, this is the first study assessing the impact of conflict on TB services in Nigeria.

- Short time span of TB data was used to highlight challenges in TB services during conflict and stimulate research for resilient approaches.

to diagnosis and treatment. ${ }^{2}$ There is a poor documentation of how TB trends change over a prolonged period in areas of conflict and scrutinising the case notifications trends in these areas may improve our understanding of the performance of TB services when operating under severe strain. ${ }^{3}$

Adamawa State, in North-east Nigeria, has experienced several years of conflict with disruption of health service delivery because of the Boko Haram insurgency. ${ }^{4-6}$ Boko Haram, which in Hausa means 'Western education is forbidden, ${ }^{, 7}$ is a militant group made up of dispersed cells and factions, which aims to make northern Nigeria an Islamic state. ${ }^{7}$ The movement was founded in 2002, initially targeting government institutions (police stations, security officers, military barracks) and conducting large-scale operations targeting religious and civil buildings and schools since 2010 to revenge the killing of its 


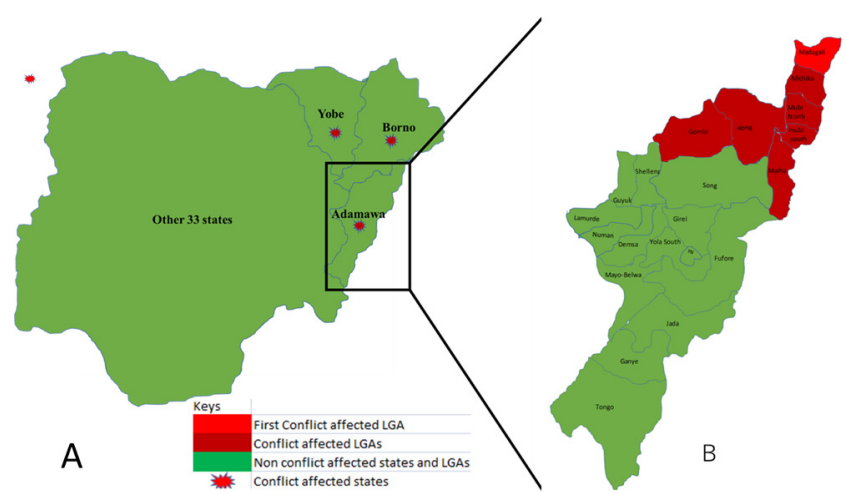

Figure 1 A map of Nigeria showing the three north-eastern states affected by insurgency (A) and local government areas (LGAs) affected by insurgency in Adamawa State, Nigeria (B).

leader in 2009. In 2013, Adamawa, Yobe and Borno states of Nigeria declared states of emergency ${ }^{8}$ and by 2014 , 16 local government areas (LGAs) had been captured by the insurgents in the North-east ${ }^{10}{ }^{11}$ with a severe disruption of public health activities ${ }^{4-6}$ and an estimated 1.7 million population displaced by June 2017 (figure 1). ${ }^{12}$ Some of the displaced persons moved to relatively safer sites within the affected areas, while others entirely left the affected areas as shown by the displacement tracking matrix produced by the UN International Organisation for Migration. ${ }^{13-15}$

In Adamawa State, seven LGAs (Gombi, Hong, Maiha, Mubi North and South, Michika and Madagali) experienced the brunt of the violence, and these remained under the control of Boko Haram until their progressive recapture by the Nigerian Army (Hong, Gombi, Maiha and Mubi by December 2014, Michika by January 2015 and Madagali by March 2015)..$^{16-21}$

Although the state of emergency was lifted in February 2014, the insurgents persisted until their dislodgement from Madagali from the aforementioned affected LGAs. ${ }^{16}$

In order to guide health operational intervention/ implementation, all the LGAs in the state (Adamawa) were categorised into high, moderate and low conflict by health policy makers and development partners in the state ministry. The categorisation was based on proximity of the LGAs to Boko Haram strongholds in Borno, the number of IDP camps, the estimated number of fatalities and damage to life and properties.

Two LGAs (Madagali and Michika) in the high conflict areas are the closest to the Boko Haram stronghold in Borno State, followed by the five LGAs (Mubi North, Mubi South, Maiha, Hong and Gombi) in the moderate conflict area and then finally the 14 farthest LGAs (Song, Girei, Yola North, Yola South, Fufore, Mayo-belwa, Jada, Ganye, Tongo, Numan, Guyuk, Lamurde, Demsa and Shelleng) are considered the low conflict areas. Thus, the conflict initially progressed from the the northern to the southern part of the state, which is farthest from the main Boko Haram camp. ${ }^{1722}$

We conducted an analysis to assess the TB case notification trends and their spatiotemporal distribution in
Adamawa State, one of the states most affected by the violence, and explored the impact that the insurgency had on TB case notification.

\section{MATERIALS AND METHODS Study design and setting}

This was a retrospective study based on TB case notifications (TB surveillance data) from 2010 to 2016 in Adamawa State, in North-east Nigeria (figure 1). Adamawa has an estimated 4.2 million population and is divided into 21 semiautonomous LGAs. ${ }^{23}$ Of the three 'BAY' states (Borno, Adamawa and Yobe) experiencing major political instability in the North-east, Adamawa was the second most affected by the insurgency. It was chosen for this study for its peculiarity of progressive recapture by the military and relative safety of travel at the time of data collection. Yobe in turn was not selected because it did not have a functional airport and insurgents abounded episodically on the highway and thus data was unreliable or not collected. Though an airport existed in Borno state, targeted bombings continue and some LGAs are still under the control of Boko Haram rendering impossible to access data.

\section{Data sources and acquisition}

Data from the TB registers of the $196 \mathrm{~TB}$ centres of all the LGAs of Adamawa State were collected by health workers under supervision of the state and LGA TB supervisors. Data collected included age, sex, treatment outcome and patient category. Aggregated data were collated at quarterly programme review meetings and submitted to the National TB, Leprosy and Buruli Ulcer Control Programme (NTBLCP). All the data for this research were obtained following approval to carry out research on anonymous aggregated data by the state ethics committee, and by September 2018, all data were sorted and ready for in-depth analysis.

\section{Data analysis}

Data were entered and cleaned in Microsoft excel sheets, and statistical analysis was performed using STATA V.13.1. Case notifications in different LGAs, areas of conflict and time points were evaluated. Case counts instead of rates were used as population census was not available and population changes were not quantified. We were thus unable to use rates due to the difficulty in having accurate population figures. Nigeria's last population census took place in 2002 and since then only population estimates are used. However, they are likely to be inaccurate in areas of protracted conflict with cumulative displacement of population. The projected population estimates therefore were considered to be unlikely to provide a reliable denominator to build the true picture of the burden of TB. The trends in numbers of case notification were therefore analysed by area of conflict, age group (0-4, $5-14,15-24,25-34,35-44,45-54,55-64$ and $\geq 65$ years), sex, forms of TB (extra pulmonary TB, smear-positive 
Table 1 Characteristics of patients with TB in Adamawa State, Nigeria, 2010-2016

\begin{tabular}{|c|c|c|c|c|c|c|c|}
\hline Characteristics & 2010 & 2011 & 2012 & 2013 & 2014 & 2015 & 2016 \\
\hline All & 2900 & 2644 & 3382 & 3460 & 2821 & 2794 & 3075 \\
\hline Female & $1080(37.2)$ & $974(36.8)$ & $1326(39.2)$ & 1359 (39.3) & 1061 (37.6) & $1016(36.4)$ & $1146(37.3)$ \\
\hline \multicolumn{8}{|l|}{ Age group } \\
\hline $0-4$ & $61(2.1)$ & $66(2.5)$ & $62(1.8)$ & 77 (2.2) & $72(2.6)$ & $80(2.9)$ & $80(2.6)$ \\
\hline $15-24$ & $442(15.2)$ & $382(14.4)$ & $478(14.1)$ & $462(13.4)$ & $373(13.2)$ & $367(13.1)$ & $418(13.6)$ \\
\hline $25-34$ & $825(28.4)$ & $750(28.4)$ & $929(27.5)$ & $849(24.5)$ & $690(24.5)$ & $692(24.8)$ & $740(24.1)$ \\
\hline $35-44$ & $622(21.4)$ & $570(21.6)$ & 731 (21.6) & $752(21.7)$ & $669(23.7)$ & $643(23.0)$ & $620(20.2)$ \\
\hline $45-54$ & $402(13.9)$ & $334(12.6)$ & $511(15.1)$ & 549 (15.9) & 449 (15.9) & $434(15.5)$ & $474(15.4)$ \\
\hline $55-64$ & $233(8.0)$ & $251(9.5)$ & $293(8.7)$ & $324(9.4)$ & $248(8.8)$ & $255(9.1)$ & $298(9.7)$ \\
\hline Extrapulmonary & $92(3.2)$ & $156(5.9)$ & $193(5.7)$ & $321(9.3)$ & $244(8.6)$ & $238(8.5)$ & $230(7.5)$ \\
\hline Smear + ve PTB & 1506 (51.9) & $1299(49.1)$ & 1977 (58.5) & 1839 (53.2) & $1594(56.5)$ & 1727 (61.8) & 1917 (62.3) \\
\hline Smear -ve PTB & $1302(44.9)$ & $1189(45.0)$ & $1212(35.8)$ & $1300(37.6)$ & $983(34.8)$ & $829(29.7)$ & $928(30.2)$ \\
\hline \multicolumn{8}{|l|}{ Patient category } \\
\hline New & 2651 (91.4) & 2357 (89.1) & 3147 (93.1) & 3195 (92.3) & 2631 (93.3) & $2682(96.0)$ & $2941(95.6)$ \\
\hline Relapse & $122(4.2)$ & $106(4.0)$ & $105(3.1)$ & $119(3.4)$ & $100(3.5)$ & $47(1.7)$ & 72 (2.3) \\
\hline Treatment failure & $18(0.6)$ & $27(1.0)$ & $17(0.5)$ & $22(0.6)$ & $15(0.5)$ & $10(0.4)$ & $15(0.5)$ \\
\hline Loss to follow-up & $50(1.7)$ & $36(1.4)$ & $36(1.1)$ & $26(0.8)$ & $17(0.6)$ & $22(0.8)$ & $13(0.4)$ \\
\hline Other & $59(2.0)$ & $118(4.5)$ & 77 (2.3) & $98(2.8)$ & $58(2.1)$ & 33 (1.2) & $34(1.1)$ \\
\hline
\end{tabular}

PTB, pulmonary tuberculosis ; TB, tuberculosis.

(+ve) and smear-negative pulmonary TB (PTB)) and treatment category (New, Relapse, Treatment failure, Loss to follow-up and Others). $\chi^{2}$ and $\chi^{2}$ for trend tests were used to analyse all the categorical data. $\mathrm{p}<0.05$ was considered statistically significant.

\section{Patient and public involvement}

No patients were involved and all data utilised for analysis was anonymous aggregated TB statistics.

The results of this research will be disseminated to the state to assist in decision making regarding the state TB programme.

\section{RESULTS}

\section{Overall TB case notifications in Adamawa State, Nigeria}

A total of 21076 TB cases (13074 (62\%) male) were notified by Adamawa State between January 2010 and December 2016 (table 1). Of these, 19604 (93\%) were new TB cases, $671(3.2 \%)$ relapses, $124(0.6 \%)$ treatment failures and $200(0.9 \%)$ were lost to follow-up. Patients aged 25-34 years represented $26 \%$ of all cases and the lowest proportion of cases occurred in 0 to 4-year-old children $(498,2.4 \%$ ) (table 1). In total, 11859 (56.3\%) and $7743(36.7 \%)$ were smear-positive and smear-negative PTB, while 1474 (7.0\%) had extrapulmonary TB.

\section{TB case notifications by LGAs and period of conflict}

Before the time of conflict, from 2010 to 2013, there were no significant changes in the notification trends in the high $\left(\chi^{2}\right.$ for trend, $\left.p=0.3\right)$, moderate $(p=0.6)$ and low conflict areas $(p=0.97)$ (figure 2$)$. However, during the conflict years, LGAs experiencing conflict reported lower numbers of cases from 2013 onwards, with a significant

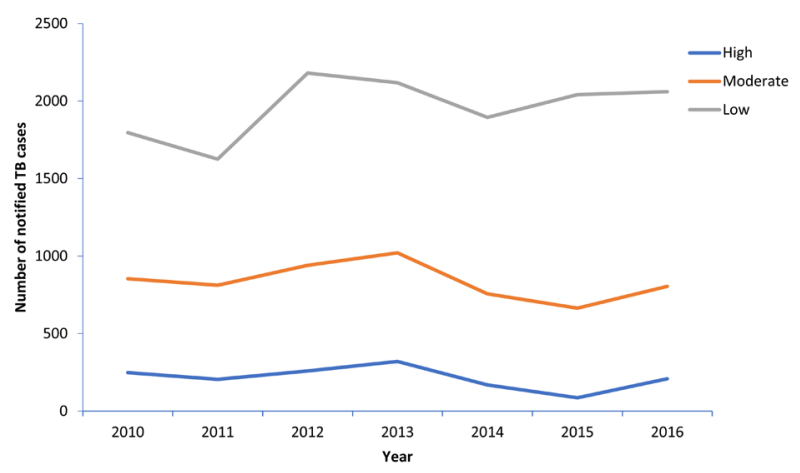

Figure 2 Number of tuberculosis (TB) case notifications by level of conflict (high, moderate and low) in Adamawa State, Nigeria. 
Table 2 TB case notification by LGAs stratified by degree of conflict, Adamawa State, 2010-2016

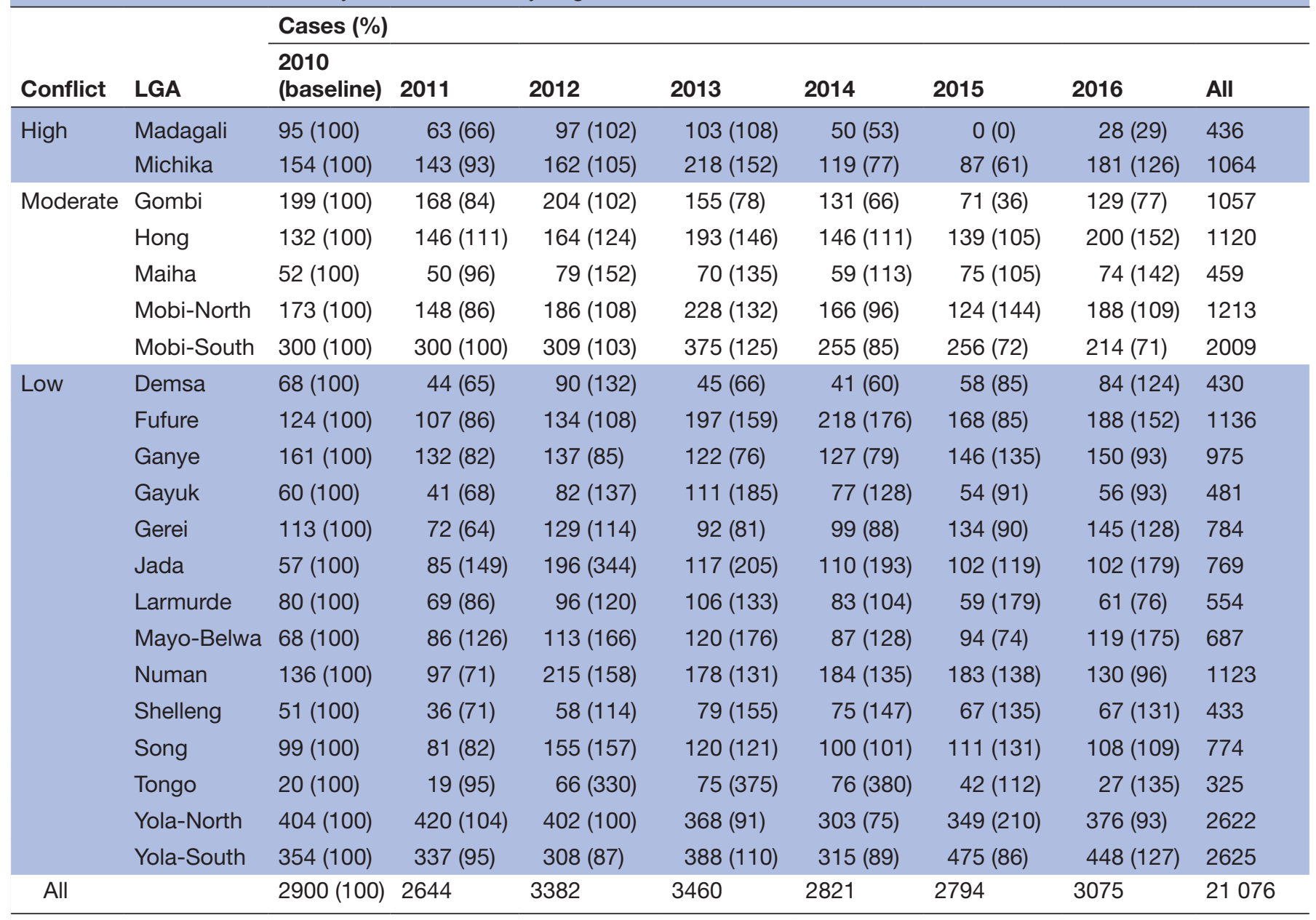

LGA, local government area; TB, tuberculosis.

decrease in case notifications in the high $\left(\chi^{2}\right.$ for trend, $\mathrm{p}=0.0001)$ and moderate conflict areas $(\mathrm{p}=0.0001)$, and a corresponding increase in case notifications in the low conflict areas $\left(\chi^{2}\right.$ for trend, $\left.\mathrm{p}=0.0001\right)$. In Madagali, the LGA with the most severe conflict, the number of cases reported declined from 103 in 2013 to 50, 0 and 28 in 2014, 2015 and 2016, respectively (table 2). Similarly, neighbouring Michika LGA experienced a decline from 228 in 2013 to 119 and 87 in 2014 and 2015, respectively. Among LGAs with moderate conflict, Mubi North experienced a progressive decline from 228 in 2013 to 166 and 124 in 2014 and 2015, respectively, while notifications in Mubi South declined from 375 in 2013 to 255, 256 and 214 in the same years and in Gombi, cases dropped from 155 in 2013 to 71 in 2015. In Hong, the cases dropped from 193 in 2013 to 71 in 2015, while Maiha LGA had a small decrease from 70 in 2013 to 59 in 2014.

During post-conflict years, from 2015 to 2016, there was an increase in case notifications in the high conflict areas $\left(\chi^{2}\right.$ for trend, $\left.\mathrm{p}=0.0001\right)$ and low conflict areas $(\mathrm{p}=0.03)$, but no significant changes was observed in areas with moderate conflict $(\mathrm{p}=0.1)$ (figure 2$)$.

\section{Trend of case notifications by sex and LGAs}

Overall, more males than females were notified (1.6 times). Before the conflict, from 2010 to 2013, there were no significant changes in the trends of notified cases by gender (males: $\mathrm{p}=0.4$; females: $\mathrm{p}=0.6$ ) in the areas with high, moderate and low conflict areas ( $p>0.7$ for all areas)

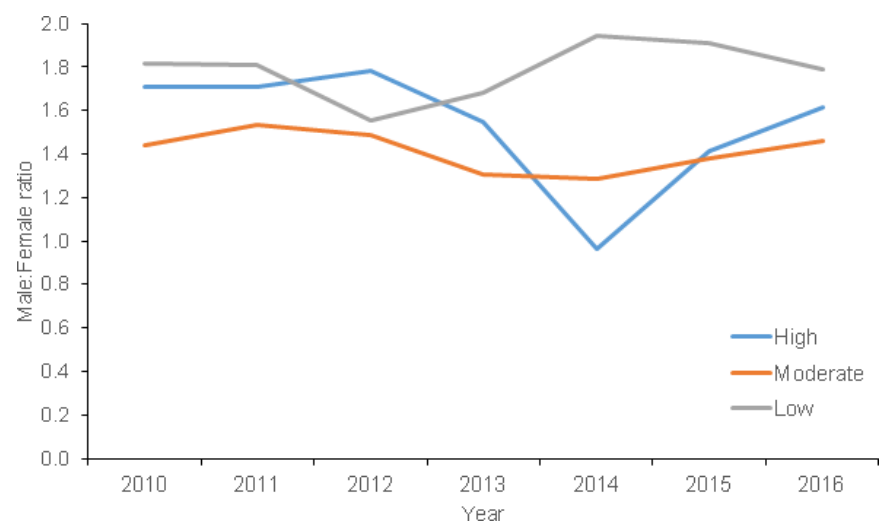

Figure 3 Tuberculosis case notifications and gender ratio (male:female) by level of conflict (high, moderate and low) in Adamawa State, Nigeria. 


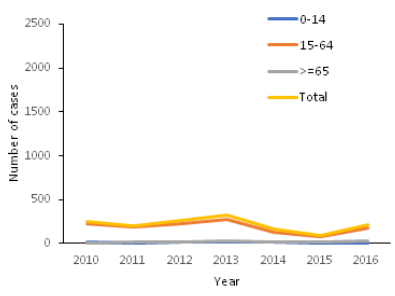

$4 \mathrm{~A}$

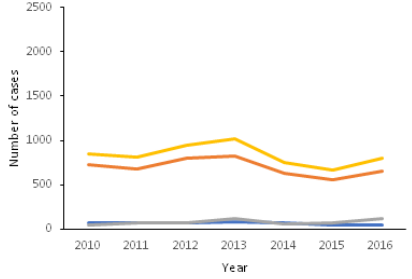

4B

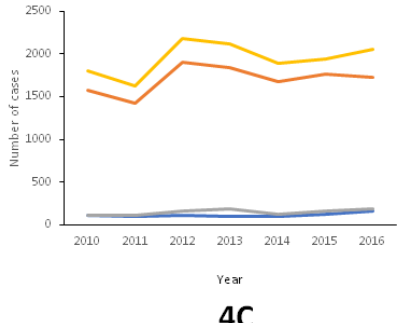

$4 C$

Figure 4 Number of tuberculosis case notification by age group and level of conflict in Adamawa State, Nigeria. Left, middle and right figures represent data from high, moderate and low conflict areas, respectively.

(figure 3). However, more female cases were notified in 2014 in areas with high (Michika) and moderate conflict (Mubi North and to some extent, Mubi South). Overall, the sex ratio (male to female) increased in low conflict areas, while the opposite occurred for moderate and very high conflict areas (figure 3).

\section{Trends of case notifications by age group and period of conflict}

There was a significant increase in case notifications among adults $\geq 65$ years between 2010 and 2016 ( $\chi^{2}$ for trend, $\mathrm{p} \leq 0.0001)$; while case notifications among 15-64 years old remained stable $(p>0.2)$ (figure 4$)$. Moreover, from 2010 to 2013, there was a significant increase in case notifications among $0-14(\mathrm{p}<0.01)$ and $\geq 65$-year-old cases $(p=0.0001)$, but no significant change occurred among 15-year-old to 64-year-old cases $(\mathrm{p}=0.5)$. Although there were no significant changes from 2010 to 2016 for the age group 0-14 and 15-64 in high conflict areas $(p>0.2$ for both age groups), there were significantly increased notifications of patients with $\mathrm{TB} \geq 65$ years old between 2010 and 2013 ( $\chi^{2}$ for trend, $\mathrm{p}<0.001$ ) (figure $4 \mathrm{~A}$ ). Among areas with moderate conflict, there was no significant change in the trend of notifications among 15-year-old to 64-year-old cases between 2010 and 2016 ( $p>0.4$ ), while there was significant decrease among 0 to 14-year-old cases $\left(\chi^{2}\right.$ for trend, $\left.\mathrm{p}=0.0139\right)$ and increase among $\geq 65$-year-old cases $\left(\chi^{2}\right.$ for trend, $\left.\mathrm{p}<0.0001\right)$ from 2010 to $2013(\mathrm{p}=0.0004)$ and 2015 to $2016(\mathrm{p}=0.0501)$ (figure $4 \mathrm{~B}$ ). In contrast, low conflict areas had a significant increase of 0-14 and $\geq 65$-year-old cases from 2010 to 2016 ( $\mathrm{p}=0.0367$ and $\mathrm{p}=0.0053$, respectively), but no significant changes among 15-year-old to 64-year-old cases $(\mathrm{p}=0.7)$ (figure 4C).

\section{DISCUSSION}

In this report, we demonstrate that political conflict impacts TB case notifications. There was gross heterogeneity and many intricate factors during the complex humanitarian emergency that affected North-east Nigeria. This heterogeneity led to some locations having lower TB notification for a few years, while others did not. Generally, years and places of higher conflict were associated with lower TB notifications. All LGAs experiencing conflict reported lower numbers of cases from 2013 onwards and the decline was more severe in the most affected areas, with corresponding increases in case notifications in low conflict areas. The decline in case notification coincided with the progressive capture of LGAs by Boko Haram, the displacement of population and disruption of health services. ${ }^{4-8} 10-12$ The lower numbers of cases notified in the places and times most likely reflected displacement of the populations to other locations that were considered safer, less access and disruption of TB services, decrease access due to transport, destruction of health facilities and desertion of health staff. As a result of these major challenges, Madagali recorded no cases in 2015, which was attributed to the severity of the conflict in this LGA. Madagali was the first LGA to be invaded and the last to be recaptured by the army. In 2015, all TB services in Madagali came to a standstill, all health staff and patients left the area and transport was unavailable. Other studies have shown similar low case notifications from areas of conflict in Sudan. ${ }^{24}$ In Adamawa State, areas of low conflict reported more case notifications than in previous years, while areas of very high conflict reported low number of cases. This is attributable to several factors, including population displacement from high conflict to relatively safe areas, displaced persons in the host communities of low conflict areas accessing the TB services, displaced populations living in poor conditions and malnutrition, with overcrowding, which facilitates transmission and disease progression and the coincidental introduction of four GeneXpert machines, which have higher sensitivity than smear microscopy, in the low conflict areas.

Most LGAs had increased notifications from 2012 to 2013. This period coincided with a TB Reach-funded project in all LGAs during which TB risk messages were broadcasted through jingles in the local radios, with the intention to increase case finding among nomadic pastoralists. At that time, health workers were re-trained on TB identification, diagnosis, treatment and follow-up and 402 community volunteers were engaged to boost awareness and reporting of cases. This intervention coupled with the introduction of GeneXpert testing increased awareness on TB and provided additional resources, possibly resulting in improved healthcare seeking behaviour, better case notification and reporting. Some LGAs also appeared to have a rebound of cases to preconflict notification levels (eg, Michika) due to a massive return of displaced populations after the recapture of the areas by 
the military. In those situations, health services resumed with varying intensity across the areas and service availability was not evenly distributed across the LGAs.

Overall, a higher number of males than females were notified. However, in areas of high and moderate conflict the sex ratio changed, with more female cases being notified. This was likely due to males avoiding contact with health services, as Boko Haram targeted males for killings and abductions. In contrast, in low conflict areas, the sex ratio increased, suggesting that males may have travelled to these relatively safe areas for health seeking.

The overall number of cases reported was lower among areas with moderate and severe conflict. Similar findings have been reported from other areas of conflict, as conflict interfere with identification and treatment of patients with TB. ${ }^{14}$ A low number of children and elderly cases were also reported in all areas, which reflects the increased difficulty in reaching a diagnosis in those age groups and the lower accessibility of services for individuals with young and advanced age. These pre-established barriers seemed to worsen within conflict areas. The low proportion of cases diagnosed in elderly groups may reflect societal and economic barriers to access the services and a cohort effect where vulnerable individuals died at early age, with the selection of the fittest. Children in turn often have low bacilli numbers, are unable to produce sputum and are more difficult to diagnose at any time, requiring skills to obtain alternative clinical samples for diagnosis (eg, gastric lavage). Added to this, their dependence on parents separated by conflict and in poverty, it is not surprising the number of cases dwindled sharply during conflict years. ${ }^{25}{ }^{26}$ Surprisingly, the trend analysis showed increasing numbers of cases in children and the elderly in preconflict and postconflict periods. This may have been due to the TB Reach intervention described above during the preconflict period and then, the return of the population to their own areas. Other studies have attributed the increasing trends in under five notifications to a higher susceptibility to TB among displaced populations and better access to diagnostics and treatment services due to humanitarian organisations providing emergency services. ${ }^{27}$

The analysis presented here needs to consider the limitations of the data. Being aggregated data, it lacks sociodemographic granularity and individual patient information to warrant detailed exploration into associations and confounders. The data was also collected from services using passive TB case finding, which is likely to underestimate the real burden of TB. Areas in conflict are also more likely to have missing cases and minimal reporting than areas that can run normal services. Population sizes are also likely to have changed substantially with the internal and international displacement of the population. A systematic review has shown instances in which forced population displacement caused by conflict in areas with a substantial TB burden is associated with decreases in the TB notification rates with increased mortality and morbidity from other infectious diseases. ${ }^{28}$

\section{CONCLUSION}

Despite these limitations, we have shown that case notifications in LGAs in conflict areas decreased during the period of insurgency. However, notification changes were not homogeneous and affected differently males and females and age groups. We believe this analysis is useful to plan TB services for areas in conflict and their neighbouring areas receiving IDPs.

\section{Author affiliations}

${ }^{1}$ Program for Nurturing Global Leaders in Tropical and Emerging Communicable Diseases, Graduate School of Biomedical Sciences, Nagasaki University, Sakamoto, Nagasaki, Japan

${ }^{2}$ Adamawa State Agency for the Control of HIV/AIDs, Yola, Nigeria

${ }^{3}$ Department of Immunogenetics, Institute of Tropical Medicine (NEKKEN), Nagasaki University, Sakamoto, Nagasaki, Japan

${ }^{4}$ Department of Pediatrics, Federal Medical Centre, Yola, Adamawa State, Nigeria ${ }^{5}$ Department of Medical Statistics and Informatics, Faculty of Public Health, University of Medicine and Pharmacy at Ho Chi Minh City, Ho Chi Minh City, Viet Nam

${ }^{6}$ Therapeutic Department, Egyptian National Blood Transfusion Services, Cairo, Egypt

${ }^{7}$ Department of Immune Regulation, Shionogi Global Infectious Diseases Division (SHINE), Institute of Tropical Medicine (NEKKEN), Nagasaki University, Nagasaki, Japan

${ }^{8}$ Institute of Research and Development, Duy Tan University, Da Nang, Vietnam ${ }^{9}$ Department of International Health and Epidemiology, Liverpool School of Tropical Medicine, Liverpool, UK

\section{Twitter Shyam Prakash Dumre @spdumre}

Acknowledgements EP is a recipient of a PhD scholarship from the Program for Nurturing Global Leaders in Tropical and Emerging Communicable Diseases, Graduate School of Biomedical Sciences, Nagasaki University. Authors appreciate Adamawa State for providing the data.

Contributors EP, SJ, LEC, KH and NTH designed the study. EP and SJ acquired the data. LEC, SPD and EP analysed the data. KH, LEC, SPD, SJ, EP and NTH interpreted the data. LEC, NTH and KH supervised the study. EP, SJ, ABU, NLV, AE, SPD, SM, NTH, LEC and KH reviewed and revised the draft. All authors critically reviewed the paper and approved the final version of the paper for submission.

Funding Nagasaki University.

Map disclaimer The depiction of boundaries on this map does not imply the expression of any opinion whatsoever on the part of BMJ (or any member of its group) concerning the legal status of any country, territory, jurisdiction or area or of its authorities. This map is provided without any warranty of any kind, either express or implied.

Competing interests None declared.

Patient consent for publication Not required.

Ethics approval Approval for the study was granted by the Federal Medical Centre Yola, which is responsible for issuing ethical approval for medical research in Adamawa State (issued 18 January 2018; Ref number FMCY/SUB/S.128/VOL.1/ $\mathrm{ABC} / \mathrm{I})$. All analysis was conducted as aggregate data and individual consent was not required.

Provenance and peer review Not commissioned; externally peer reviewed.

Data availability statement Data are available upon reasonable request. The datasets used and/or analysed during the current study are available from the corresponding author on reasonable request.

Open access This is an open access article distributed in accordance with the Creative Commons Attribution Non Commercial (CC BY-NC 4.0) license, which permits others to distribute, remix, adapt, build upon this work non-commercially, and license their derivative works on different terms, provided the original work is properly cited, appropriate credit is given, any changes made indicated, and the use is non-commercial. See: http://creativecommons.org/licenses/by-nc/4.0/.

ORCID iD

Kenji Hirayama http://orcid.org/0000-0001-9467-1777 


\section{REFERENCES}

1 UkwajaK, Alobul, IfebunanduN, et al. From dots to the stop TB strategy: dots coverage and trend of tuberculosis notification in Ebonyi, southeastern Nigeria, 1998-2009. Pan Afr Med J 2011;9:12.

2 Rodger AJ, Toole M, Lalnuntluangi B, et al. Dots-Based tuberculosis treatment and control during civil conflict and an HIV epidemic, Churachandpur district, India. Bull World Health Organ 2002;80:451-6.

3 Dangisso MH, Datiko DG, Lindtjørn B. Trends of tuberculosis case notification and treatment outcomes in the Sidama zone, southern Ethiopia: ten-year retrospective trend analysis in urban-rural settings. PLoS One 2014;9:e114225.

4 UNDP. Livelihood and economic recovery assessment, 2016.

5 Omole $\mathrm{O}$, Welye $\mathrm{H}$, Abimbola S. Boko Haram insurgency: implications for public health. Lancet 2015;385:941.

6 UNICEF. Annual report. Nigeria. 2015, 2015.

7 Cable News Network. Boko Haram fast facts, 2018. Available: https://edition.cnn.com/2014/06/09/world/boko-haram-fast-facts/ index.html

8 Dunn G. The impact of the Boko Haram insurgency in Northeast Nigeria on childhood wasting: a double-difference study. Confl Health 2018;12:6.

9 Vanguard Media Limited, Nigeria. Jonathan declares state of emergency in Borno, Yobe, Adamawa. Available: https://www. vanguardngr.com/2013/05/breaking-news-jonathan-declares-stateof-emergency-in-borno-yobe-adamawa/

10 GMCL. Boko Haram has so far captured 16 local government areas, group says, 2014. Available: http://www.greenbreporters.com/news/ crime/boko-haram-far-captured-16-local-government-areas-groupsays.html

115,247 killed in Boko Haram militancy in Nigeria's Adamawa since 2013. Trend news agency 2017. Available: https://en.trend.az/world/ other/2842873.html

12 UNHCR. Nigeria situation, 2017.

13 IOM. Displacement tracking matrix 2014 : round 02 dashboard of baseline assessment Nigeria, 2014.

14 Gele AA, Bjune GA. Armed conflicts have an impact on the spread of tuberculosis: the case of the Somali regional state of Ethiopia. Confl Health 2010;4:1.

15 The Displacement Tracking Matrix. Nigeria: West and Central Africa. Available: https://dtm.iom.int/nigeria
16 Vanguard Media Limited, Nigeria. Military recaptures Madagali, last area held by Boko Haram in Adamawa. Available: https://www. vanguardngr.com/2015/03/military-recaptures-madagali-last-areaheld-by-boko-haram-in-adamawa/

17 AllAfrica. Nigeria: military recaptures Madagali, last area held by Boko Haram in Adamawa. Available: https://allafrica.com/stories/ 201503130289.htm

18 The Premium Times, Nigeria. Military recaptures Michika town from Boko Haram, says Jonathan. Available: https://www. premiumtimesng.com/regional/nnorth-east/175958-militaryrecaptures-michika-town-boko-haram-says-jonathan.html

19 BellaNaija. Military has recaptured Michika town from Boko Haram - PRES. Jonathan. Available: https://www.bellanaija.com/2015/ 01/military-has-recaptured-michika-town-from-boko-haram-presjonathan/

20 Vanguard Media Limited, Nigeria. Boko Haram: army recaptures Mubi, Gombi, Maiha, Hong Council areas. Available: https://www. vanguardngr.com/2014/12/boko-haram-army-recaptures-mubigombi-maiha-hong-council-areas/

21 Vanguard Media Limited, Nigeria. Military recaptures Gombi, Hong, Pella from Boko Haram. Available: https://www.vanguardngr.com/ 2014/11/military-recaptures-gombi-hong-pella-boko-haram/

22 PUNCH. Boko Haram: horror in Adamawa. Available: https:// punchng.com/boko-haram-horror-in-adamawa/

23 Statistics NBo. Annual Abstract of Statisitics. National Bureau of stattistics, Nigeria, 2012.

24 Hassanain SA, Edwards JK, Venables E, et al. Conflict and tuberculosis in Sudan: a 10-year review of the National tuberculosis programme, 2004-2014. Confl Health 2018;12:18.

25 Seddon JA, Jenkins HE, Liu L, et al. Counting children with tuberculosis: why numbers matter. Int J Tuberc Lung Dis 2015;19:9-16.

26 Oshi DC, Chukwu JN, Nwafor CC, et al. Does intensified case finding increase tuberculosis case notification among children in resource-poor settings? A report from Nigeria. Int J Mycobacteriol 2016;5:44-50.

27 van Rie A, Beyers N, Gie RP, et al. Childhood tuberculosis in an urban population in South Africa: burden and risk factor. Arch Dis Child 1999;80:433-7.

28 Kimbrough W, Saliba V, Dahab M, et al. The burden of tuberculosis in crisis-affected populations: a systematic review. Lancet Infect Dis 2012;12:950-65. 